\title{
Initial effects of the grounding of the tanker Braer on health in Shetland
}

\author{
D Campbell, D Cox, J Crum, K Foster, P Christie, \\ D Brewster on behalf of the Shetland Health Study Group
}

\begin{abstract}
Objective-To determine if the oil spillage from the tanker Braer had any immediate health effects on the exposed resident population.

Design-Cohort study with a comparison against controls, exposure status being assigned on the basis of geographical location.

Setting-Rural Shetland.

Subjects-All those resident on or after 5 January 1993 (day 0) within $4.5 \mathrm{~km}$ of the site of tanker's grounding. Controls matched for sex and age were drawn from a general practice list $95 \mathrm{~km}$ distant.

Outcome measures-Demographic details; smoking and alcohol consumption; perception of health and reported presence or absence of specific symptoms; peak expiratory flow; results of haematology, liver and renal function tests, and blood and urine toxicology.
\end{abstract}

Results-Of subjects contacted, $420 \quad(66 \%)$ exposed people and $92(68 \%)$ controls were studied; 56 non-attenders were surveyed. Principal health effects arose on days 1 and 2 and were headache, throat irritation, and itchy eyes. No significant differences between those exposed and controls were found for any of the biological markers. Toxicological studies did not show any exposures that are known to affect human health.

Conclusions-The study confirmed the anecdotal reports of certain acute symptoms. No evidence of pulmonary, haematological, renal, or hepatic damage was detected at the population level. Toxicological samples from exposed people did not find levels known to affect human health. Further studies are required to ascertain whether there have been any long term effects on the population.

Environmental Health

(Scotland) Unit, Ruchill Hospital, Glasgow G20 9NB

D Campbell, consultant in public health medicine

Shetland Health Board, Lerwick, Shetland ZE1 0RB

D Cox, director of public health

$\mathrm{J}$ Crum, research associate

Grampian Health Board, Aberdeen AB9 1RE

$\mathrm{K}$ Foster, senior registrar

Common Services Agency for Scottish Health Service, Edinburgh EH5 3SQ

P Christie, senior registrar

D Brewster, senior registrar

Correspondence to:

- Dr Campbell.

$B M 71993 ; 307: 1251-5$

\section{Introduction}

On 5 January 1993 the tanker MV Braer on passage from Norway to Quebec ran aground on Garth's Ness, a rocky headland on the south west of Shetland. ${ }^{1}$ Over the next six days it leaked its cargo of 85000 tonnes of Norwegian Gullfaks crude oil, the maximum discharge occurring as the ship broke up on 11 January. Concerns were expressed as to the immediate and long term health effects on the exposed population, public anxiety being exacerbated by statements from individuals and organisations. There were anecdotal reports of acute toxic symptoms, mainly of shortlived types related to exposure. ${ }^{2}$ The volatile nature of the oil and the extreme weather conditions resulted in it being blown over the land to the north and east of the vessel, exposing soil, crops, buildings, animals, and humans to hydrocarbons as vapour, droplets, and oil-water emulsions. Dispersants were sprayed and fell over land as well as sea. ${ }^{3}$ Some of the constituents of the oil were known to be potentially carcinogenic. ${ }^{4}$

Environmental exposure to crude oil and its components may occur by ingestion, inhalation, or dermal absorption. The release from the Braer would have generated aerosols from wind and wave action and vapours by evaporation. Most of the aerosol would have settled on surfaces or been filtered by the nose and mouth, only a small proportion of droplets being in the respirable range. Shetland Islands Council's detailed environmental sampling started on 10 January, estimating vapour, particulates, and settled and precipitated material (measuring hydrocarbons of lengths $\mathrm{C}_{3}$ to $\mathrm{C}_{16}$ ). Hydrocarbon concentrations were measured in the public raw drinking water and in soil and vegetable samples. The highest estimated airborne hydrocarbon concentration $(6.33 \mathrm{ppm})$ occurred on 11 January, the day the tanker broke up, at the dwelling nearest the wreck, with a corresponding benzene concentration of $0.074 \mathrm{ppm}$. On 10 January the concentrations at the same site were $0.264 \mathrm{ppm}$ and $0.023 \mathrm{ppm}$ and on 12 January, $0.066 \mathrm{ppm}$ and 0.018 ppm ( $P$ Leinster and $\mathrm{N} E$ Thomson, report to environmental services department, Shetland Islands Council).

Epidemiological investigations of major oil spillages have been undertaken infrequently and have focused on workers involved in cleanup operations rather than exposed residents, and performed only at later stages in the incidents. ${ }^{56}$ Studies on hydrocarbon hazards have concentrated on occupational rather than residential exposures, emphasising chronic rather than acute exposures. ${ }^{7}$ This study was designed to determine the immediate effects of the oil spillage on the health of the Shetland population with the objectives of collecting baseline information from and performing biological measurements on a group of residents potentially exposed to the spillage. This project did not offer "health checks," which are a clinical matter between individuals and their general medical or occupational health practitioner. ${ }^{8}$ Approval was granted by Shetland Health Board's research ethics committee; data collection started on 13 January and was completed on 21 January 1993.

\section{Methods}

The exposed group was defined as those permanently resident within a $4.5 \mathrm{~km}$ radius of Garth's Ness and present within this area at any time from and including 5 January 1993, a decision based on the geographical area most affected and a practical study size. With the assistance of the local primary health team individuals were invited to the study centre or, if housebound, offered a home visit. The unaffected location of Hillswick, $95 \mathrm{~km}$ north of the incident, was used as a control area. Detection of a difference between the exposed group and controls at the $5 \%$ level with $80 \%$ power, assuming a $10 \%$ symptom rate in those exposed and a $3.5 \%$ rate in controls, was estimated to require 136 subjects. Two hundred controls, matched for sex and 20 year age group distributions, were randomly selected. Those who confirmed no contact with the study area from the onset of the incident were invited to participate.

Information was collected by using a structured questionnaire, piloted in a rural medical practice elsewhere in Scotland. This covered personal details, medical history, current drug treatment, perception of 
health, and presence or absence and date of onset of specific symptoms occurring both during the two weeks preceding the wreck and also from the time of the wreck until the interview. Definitions of symptoms were not given and clinical examinations were not performed. As a proxy for exposure dose, participants were asked to identify whether their activities since 5 January (designated day 0) had been principally inside or outside a building. Owing to their nonuniform geographic distribution it was not possible to allocate degrees of exposure on the basis of participants' place of residence. A telephone survey was performed of non-participants within the exposed population, utilising a one in four systematic sample with substitution. Resource constraints precluded any follow up of control non-participants.

Height and weight were measured and respiratory function estimated by peak expiratory flow (MiniWright, Clement Clarke). Samples of urine and venous blood were obtained. Urine was analysed for sugar, protein, and blood (Labstix, Bayer Diagnostics), and laboratory testing carried out for hydrocarbon toxicological markers-methylhippuric isomers and ratios of hippurate to creatinine. Haemoglobin concentrations, platelet counts, and red blood and white blood cell counts were determined on venous blood. Biochemical tests were performed for liver function (aspartate aminotransferase, alamine aminotransferase, and $\gamma$-glutamyltransferase), for renal function (creatinine and urea), and toxicologically for hydrocarbons. Children under 5 years were excluded from venepuncture and peak expiratory flow measurements. All results were reported to individual's general medical practitioners, from whom they were available to participants.

Data handling and analyses were performed using

TABLE I-Characteristics of study participants by exposure categories. Values are numbers (percentages) unless indicated otherwise

\begin{tabular}{|c|c|c|c|c|c|c|}
\hline & \multicolumn{2}{|c|}{ All subjects } & \multicolumn{2}{|c|}{ Exposure inside } & \multicolumn{2}{|c|}{ Exposure outside } \\
\hline & $\begin{array}{l}\text { Exposed } \\
(n=420)\end{array}$ & $\begin{array}{l}\text { Controls } \\
(n=92)\end{array}$ & $\begin{array}{l}\text { Exposed } \\
(n=313)\end{array}$ & $\begin{array}{c}\text { Controls } \\
(n=62)\end{array}$ & $\begin{array}{l}\text { Exposed } \\
(n=107)\end{array}$ & $\begin{array}{c}\text { Controls } \\
(n=30)\end{array}$ \\
\hline \multicolumn{7}{|l|}{ Sex } \\
\hline Male & 199 & 46 & 118 & 27 & 81 & 19 \\
\hline Female & 221 & 46 & 195 & 35 & 26 & 11 \\
\hline Mean weight $(\mathrm{kg})$ & 66.5 & $76 \cdot 3$ & $63 \cdot 1$ & 61.9 & $76 \cdot 3$ & $78 \cdot 3$ \\
\hline Mean height $(\mathrm{cm})$ & $159 \cdot 4$ & $159 \cdot 4$ & $115 \cdot 7$ & $157 \cdot 0$ & $171 \cdot 0$ & $164 \cdot 2$ \\
\hline Mean age (years) & $39 \cdot 1$ & 38.3 & $38 \cdot 1$ & $34 \cdot 7$ & 42.1 & 45.6 \\
\hline \multicolumn{7}{|l|}{ Age group } \\
\hline $0-19$ & $109(26)$ & $24(26)$ & $95(30)$ & $20(32)$ & $14(13)$ & $4(13)$ \\
\hline $20-39$ & $111(26)$ & $31(34)$ & $76(24)$ & $24(39)$ & $35(33)$ & $7(23)$ \\
\hline $40-59$ & $114(27)$ & $16(17)$ & $73(23)$ & $5(8)$ & $41(39)$ & $11(36)$ \\
\hline$\geqslant 60$ & $86(21)$ & $21(23)$ & $69(22)$ & $13(21)$ & $17(15)$ & $8(26)$ \\
\hline Smokers & $92(28)$ & $19(21)$ & $61(20)$ & $15(26)$ & $31(29)$ & $4(13)$ \\
\hline No/day & $16 \cdot 2$ & $16 \cdot 1$ & $15 \cdot 4$ & $18 \cdot 4$ & $17 \cdot 7$ & 7.5 \\
\hline Drinkers & $234(56)$ & $64(70)$ & $153(49)$ & $40(65)$ & $81(76)$ & $24(80)$ \\
\hline Units/week & 6.6 & $4 \cdot 6$ & 5.4 & 3.8 & 8.8 & 5.8 \\
\hline
\end{tabular}

the EPI INFO series of computer programs. ${ }^{9}$ For categorical data $\chi^{2}$ values (derived with the MantelHaenzel formula) or Fisher exact tests with two tailed probability were computed; hypothesis testing was performed by determining odds ratios and confidence intervals, using discordant pairs where applicable. Means and $95 \%$ confidence intervals were calculated for continuous data.

\section{Results}

A total of 681 people were identified as eligible for study, 635 of whom were contacted; 412 attended the study centre and eight received home visits $(66 \%$ response rate). Fifty six non-attenders were surveyed. There were no significant differences with respect to sex and 20 year age groups between the participants and either the study population or the nonparticipants. Of the 140 eligible, contacted controls, 92 $(66 \%)$ participated. Those exposed showed no differences in age group, sex, or cigarette smoking from the controls, though there was a significant difference with respect to alcohol consumption $\left(56 \% v 70 \%, \chi^{2}=5 \cdot 75\right.$, $\mathrm{df}=1, \mathrm{p}<0.02)$. There were significant differences in sex $\left(\chi^{2}=44.68, \mathrm{df}=1, \mathrm{p}<0.0001\right)$ and age groups $\left(\chi^{2}=\right.$ $21.20, \mathrm{df}=3, \mathrm{p}<0.0001)$ between those exposed mainly inside or outside, with greater proportions of female subjects $(62 \% v 24 \%)$ and of those aged less than 20 years in the inside group (table I).

No significant differences were detected between the exposed and control groups in perception of health and of symptoms experienced in the two weeks before the incident apart from a greater proportion of sore throats in the control group. When exposed participants' perceptions of their own health and symptoms after the spillage were compared with those experienced beforehand, significant differences were found with respect to headache, throat irritation, skin irritation, itchy eyes, and mood change; differences of lower orders were found for tiredness, diarrhoea, nausea, wheezing, cough, and chest ache. Within the control group there were significant differences in proportions reporting throat irritation and runny noses before and after the wreck. Comparing exposed participants against controls after the incident identified significant differences for headache, throat irritation, and itchy eyes and weaker differences for tiredness, nausea, and skin irritation. Within the exposed group there were no differences between those exposed mainly inside or outside apart from throat irritation; runny eyes also closely approached significance. There were no differences in symptoms between exposed participants and non-participants apart from aches and pains and breathlessness at rest (table II).

TABLE II-Symptoms reported by participants by exposure categories and associations

\begin{tabular}{|c|c|c|c|c|c|c|c|c|c|c|c|c|c|c|}
\hline & \multicolumn{3}{|c|}{ Exposed group $(\mathrm{n}-420)$} & \multicolumn{3}{|c|}{ Control group (n-92) } & \multicolumn{2}{|c|}{ Exposed $v$ controls } & \multicolumn{6}{|c|}{ Exposed group after incident } \\
\hline & $\begin{array}{l}\text { No (\%) } \\
\text { before }\end{array}$ & $\begin{array}{c}\text { No }(\%) \\
\text { after }\end{array}$ & $\begin{array}{c}\text { Odds ratio }{ }^{*}(95 \% \\
\text { confidence } \\
\text { interval) }\end{array}$ & $\begin{array}{l}\text { No }(\%) \\
\text { before }\end{array}$ & $\begin{array}{l}\text { No }(\%) \\
\text { after }\end{array}$ & $\begin{array}{c}\text { Odds ratio* }(95 \% \\
\text { confidence } \\
\text { interval) }\end{array}$ & $\begin{array}{l}\text { Odds ratio }(95 \% \\
\text { confidence } \\
\text { interval) before } \\
\text { incident }\end{array}$ & $\begin{array}{l}\text { Odds ratio }(95 \% \\
\text { confidence } \\
\text { interval) after } \\
\text { incident }\end{array}$ & $\begin{array}{c}\text { No }(\%) \text { of } \\
\text { participants } \\
(n=420)\end{array}$ & $\begin{array}{l}\text { No }(\%) \text { of } \\
\text { non- } \\
\text { participants } \\
(n-59)\end{array}$ & $\begin{array}{l}\text { Odds ratio }(95 \% \\
\text { confidence } \\
\text { interval) }\end{array}$ & $\begin{array}{c}\text { No (\%) } \\
\text { inside } \\
\text { (n=313) }\end{array}$ & $\begin{array}{l}\text { No }(\%) \\
\text { outside } \\
(n-107)\end{array}$ & $\begin{array}{l}\text { Odds ratio (95\% } \\
\text { confidence } \\
\text { interval) }\end{array}$ \\
\hline Aches and pains & $85(20)$ & $92(22)$ & $1.54(0.77$ to 3.10$)$ & $24(26)$ & $25(27)$ & $1.50(0.25$ to 8.98$)$ & $0.72(0.41$ to 1.26$)$ & $0.75(0.43$ to 1.31$)$ & $92(22)$ & $3(5)$ & $4.96(1.45$ to 20.43$)$ & $70(22)$ & $22(21)$ & $1.11(0.63$ to 1.99$)$ \\
\hline Tiredness & $67(16)$ & $86(20)$ & $1.86(1 \cdot 11$ to 3.13$)$ & $14(15)$ & $8(9)$ & $0.25(0.05$ to 1.18$)$ & $1.06(0.54$ to 2.09$)$ & $2.70(1.20$ to 6.33$)$ & $86(20)$ & $5(9)$ & $2.63(0.97$ to 7.72$)$ & $64(20)$ & $22(21)$ & $0.99(0.56101 .78)$ \\
\hline Headache & $57(14)$ & $135(32)$ & $4.25(2.72$ to 6.63$)$ & $10(11)$ & $7(8)$ & $0.40(0.08$ to 2.06$)$ & $1.29(0.60$ to 2.83$)$ & 5.75 (2.47 to 14.08$)$ & $135(32)$ & $12(22)$ & $1.74(0.85$ to 3.60$)$ & $104(33)$ & $31(29)$ & $1.22(0.73+02.04)$ \\
\hline Poor appetite & $25(6)$ & $40(9)$ & $1.65(0.90$ to 3.01$)$ & $1(1)$ & $2(2)$ & $2.00(0.18$ to 22.06) & $5.79(0.81$ to 118.26$)$ & $4.35(0.99$ to 26.93$)$ & $40(9)$ & $6(11)$ & $1.20(0.52$ to 2.81$)$ & $34(10)$ & $9(8)$ & $1.50(0.39$ to 6.86$)$ \\
\hline Vomiting & $18(4)$ & $16(4)$ & $1.09(0.48$ to 2.47$)$ & $2(2)$ & $2(2)$ & $1.00(0 \cdot 14$ to $7 \cdot 10)$ & $1.67(0.35$ to 10.89$)$ & $1.78(0.38$ to 11.58$)$ & $16(4)$ & $1(2)$ & $7 \cdot 18(0 \cdot 29$ to $44 \cdot 90)$ & $13(4)$ & $3(3)$ & $1.50(0.39$ to 6.86$)$ \\
\hline Diarrhoea & $17(4)$ & $37(8)$ & $2.67(1.38$ to 5.18$)$ & $1(1)$ & 0 & & $3.84(0.52$ to 79.71$)$ & & $37(8)$ & $2(4)$ & $2.61(0.59$ to 16.11$)$ & $26(8)$ & $11(10)$ & $0.79(0.36$ to 1.79$)$ \\
\hline Nausea & $25(6)$ & $44(10)$ & $2.19(1.21$ to 3.96$)$ & $4(4)$ & $3(3)$ & $0.67(0.11$ to 4.01$)$ & $1.39(0.44$ to 4.90$)$ & $3.47(1.00$ to 14.51$)$ & $44(10)$ & $4(7)$ & $1.81(0.60$ to 6.17$)$ & $35(11)$ & $9(8)$ & $1.37(0.60$ to 3.21$)$ \\
\hline Fever & $11(3)$ & $17(4)$ & $1.75(0.72$ to 4.17$)$ & $6(7)$ & $1(1)$ & $0.17(0.02$ to 1.41$)$ & $0.39(0.13$ to 1.22$)$ & $3.84(0.52$ to 79.71$)$ & $17(4)$ & 1 (2) & $2.32(0.32$ to 47.68$)$ & $14(5)$ & $3(3)$ & $1.62(0.42$ to 7.34$)$ \\
\hline Throat irritation & $43(10)$ & $154(37)$ & $5.27(3.47$ to 8.01$)$ & $18(20)$ & $7(8)$ & $0.31(0.11$ to 0.85$)$ & $0.47(0.25$ to 0.90$)$ & $7.03(3.02$ to 17.18$)$ & $154(37)$ & $14(25)$ & 1.74 (0.88 to 3.45$)$ & $105(34)$ & $49(46)$ & $0.60(0.37$ to 0.96$)$ \\
\hline Earache & $9(2)$ & $16(4)$ & $2.00(0.81$ to 4.96$)$ & $5(5)$ & $5(5)$ & & $0.34(0.10$ to 1.35$)$ & $1.78(0.38$ to 11.58$)$ & $16(4)$ & $2(4)$ & $1.07(0.23$ to 6.93$)$ & $13(4)$ & $3(3)$ & $1.50(0.39$ to 6.86$)$ \\
\hline Skin irritation & $14(3)$ & $65(15)$ & $42 \cdot 0(7 \cdot 19$ to $376 \cdot 15)$ & $5(5)$ & $6(7)$ & $2.00(0.18+022.06)$ & $0.60(0.19$ to 1.98$)$ & $2.62(1.04$ to 7.02$)$ & $65(15)$ & $7(13)$ & $1.28(0.53$ to 3.25$)$ & $48(15)$ & $17(16)$ & $0.96(0.50+01.84)$ \\
\hline Itchy eyes & $17(4)$ & $117(28)$ & $26.0(9.58$ to 70.58$)$ & $5(5)$ & $5(5)$ & $1.00(0.20$ to 4.95$)$ & $0.73(0.24$ to 2.36$)$ & $6.72(2.53$ to 19.45$)$ & $117(28)$ & $9(16)$ & $2.02(0.92$ to 4.52$)$ & $79(25)$ & $38(36)$ & $0.61(0.37$ to 1.01$)$ \\
\hline Runny nose & $58(14)$ & $75(18)$ & $1.50(0.97$ to 2.32$)$ & $29(31)$ & $14(15)$ & $0.29(0.18$ to 0.72$)$ & $0.35(0.20$ to 0.61$)$ & $1.21(0.62$ to 2.38$)$ & $75(18)$ & $9(16)$ & $1.23(0.55$ to 2.81$)$ & $57(18)$ & $18(17)$ & $1 \cdot 10(0.59$ to 2.07$)$ \\
\hline Wheezing & $25(6)$ & $39(9)$ & $3.00(1.28$ to 7.06$)$ & $5(5)$ & $5(5)$ & $0.67(0.11$ to 4.01$)$ & $0.91(0.34$ to 2.57$)$ & $1.78(0.64$ to 5.35$)$ & 39 (9) & $6(11)$ & $0.85(0.32$ to 2.37$)$ & $28(9)$ & $11(10)$ & $0.86(0.39$ to 1.92$)$ \\
\hline Breathless at rest & $6(1)$ & $8(2)$ & $2.00(0.37$ to 10.92$)$ & $1(1)$ & $1(1)$ & & $1.32(0.15$ to 29.92$)$ & $1.77(0.22$ to 38.78$)$ & $8(2)$ & $1(2)$ & 3.48 (0.49 to 70.38$)$ & $7(2)$ & $1(1)$ & $2.42(0.29$ 10 53.95) \\
\hline Breathless on exercise & $34(8)$ & $35(8)$ & $1.20(0.40$ to 3.57$)$ & $5(5)$ & $5(5)$ & & $1.54(0.55$ to 4.65$)$ & $1.30(0.50$ to 3.60$)$ & $35(8)$ & $6(11)$ & $0.16(0.05$ to 0.55$)$ & $31(10)$ & $4(4)$ & $2.83(0.91$ to 9.80$)$ \\
\hline Chest ache & $12(3)$ & $25(6)$ & $3.20(1.28$ to 8.01$)$ & $4(4)$ & $4(4)$ & 1.00 & $0.65(0.19$ to 2.47$)$ & $1.39(0.44$ to 4.90$)$ & $25(6)$ & $1(2)$ & $5.00(0.71$ to 100.08$)$ & $15(5)$ & $10(9)$ & $0.49(0.20101 .22)$ \\
\hline Cough & $55(13)$ & $75(18)$ & $1.80(1.10$ to 2.93$)$ & $23(25)$ & $16(17)$ & $0.50(0.20 \mathrm{to} 1.2$ & $0.45(0.25$ to 0.82$)$ & $1.03(0.55$ to 1.97$)$ & $75(18)$ & $7(13)$ & $1.52(0.63$ to 38.33$)$ & $54(17)$ & $21(20)$ & $0.85(0.47$ to 1.56$)$ \\
\hline Mood change & $18(4)$ & $74(18)$ & $8.00(3.84$ to 16.68$)$ & $7(7)$ & $8(9)$ & $1.50(0.25$ to 8.98$)$ & $0.54(0.20$ to 1.50$)$ & $2.25(0.99$ to 5.28$)$ & $74(18)$ & $10(17)$ & $1.00(0.50$ to 2.39$)$ & $51(16)$ & $23(22)$ & $0.71(0.39$ to 1.29$)$ \\
\hline
\end{tabular}




\begin{tabular}{|c|c|c|c|c|c|c|}
\hline & \multicolumn{2}{|c|}{ All subjects } & \multicolumn{2}{|c|}{ Outside exposure } & \multicolumn{2}{|c|}{ Inside exposure } \\
\hline & Control group & Exposed group & Control group & Exposed group & Control group & Exposed group \\
\hline \multirow{14}{*}{$\begin{array}{l}\text { Respiratory function: } \\
\text { Peak flow } \\
\text { Haematology: } \\
\text { White blood cells } \\
\text { Haemaglobin } \\
\text { Red blood cells } \\
\text { Platelets } \\
\text { Renal function: } \\
\text { Creatinine } \\
\text { Urea } \\
\text { Liver function: } \\
\text { y-Glutamyltransferase } \\
\text { Aspartate } \\
\text { aminotransferase } \\
\text { Alanine }\end{array}$} & $(\mathrm{n}=88)$ & $(n=397)$ & $(n=29)$ & $(n=104)$ & $(\mathrm{n}=59)$ & $(n=293)$ \\
\hline & $36.67(408.58$ to 462.76$)$ & $419.77(406.83$ to 432.71$)$ & $466.90(422.96$ to 510.84$)$ & $495.08(472.85$ to 517.31$)$ & 420.32 (386.61 to 454.04$)$ & 393.04 (378.56 to 4 \\
\hline & $(\mathrm{n}=78)$ & $(n=384)$ & $(n=27)$ & $(n=102)$ & $(n=51)$ & $82)$ \\
\hline & $7.50(7.05$ to 7.95$)$ & $7.52(7.30$ to 7.74$)$ & $(6 \cdot 40$ to $8 \cdot 15)$ & $7.35(6.96$ to 7.74$)$ & $7 \cdot 74(7 \cdot 16$ to $8 \cdot 32)$ & $7.50(7.05$ to 7.95$)$ \\
\hline & $14 \cdot 19(13.88$ to 14.50$)$ & $14 \cdot 38(14 \cdot 24$ to $14 \cdot 52)$ & $16.63(16.06$ to 17.20$)$ & $14.95(14.71$ to $15 \cdot 19)$ & $13.95(13.61$ to 14.29$)$ & $14 \cdot 18(14 \cdot 02$ to $14 \cdot 34)$ \\
\hline & $4.73(4.65$ to 4.81$)$ & $4.78(4.74$ to 4.82$)$ & $4.90(4.74$ to 4.74$)$ & $4.86(4.78$ to 4.94$)$ & $4.65(4.55$ to 4.74$)$ & $4.75(4.69$ to 4.81$)$ \\
\hline & 73.85 (258.17 to 289.53$)$ & $284: 29(278 \cdot 16$ to $290 \cdot 42)$ & $267.04(249.97$ to 284.11$)$ & $275.06(265.48$ to 284 . & $277 \cdot 45$ (255.18 to $299 \cdot 72)$ & $287.62(285.05$ to 295.19$)$ \\
\hline & $(n=76)$ & $(\mathrm{n}=388)$ & $(n=26)$ & $(\mathrm{n}=103)$ & $(\mathrm{n}=50)$ & $(\mathrm{n}=285)$ \\
\hline & $88.64(85.05$ to 92.23$)$ & $92.62(90.62$ to 94.62$)$ & $96.04(90.87$ to 101.21$)$ & $99.22(96.03$ to 102.41$)$ & $84.88(80.51$ to 89.25$)$ & $90.24(87.73$ to 92.75$)$ \\
\hline & $5.83(5.48$ to 6.18$)$ & $5.76(5.56$ to 5.96$)$ & $6.25(5.72$ to 6.78$)$ & $6.00(5.67$ to 6.33$)$ & $5.61(5 \cdot 16$ to $6 \cdot 06)$ & $5.68(5.44$ to 5.92$)$ \\
\hline & $(n=76)$ & $(n=388)$ & $(n=26)$ & $(\mathrm{n}=103)$ & & \\
\hline & $25.96(20.90$ to 31.02$)$ & $27.93(24.68$ to $31 \cdot 18)$ & $36 \cdot 12(25.30$ to $46 \cdot 94)$ & $35.18(25.79$ to 44.57$)$ & $20.68(15.97$ to 25.39$)$ & $25.30(22.52$ to 28.08$)$ \\
\hline & 24.51 (22.59 to 26.43$)$ & 25.68 (24.86 to 26.50$)$ & 28.15 (24.31 to 31.99$)$ & 26.55 (25.10 to 28.00$)$ & 22.62 (20.64 to 24.60$)$ & 25.36 (24.38 to 26.34$)$ \\
\hline & 24.51 (19.96 to 29.06$)$ & $23.92(22.51$ to 25.53$)$ & $35.38(24.33$ to 46.43$)$ & $27.53(24.61$ to 30.45$)$ & $18.86(16.00$ to 21.72$)$ & $22 \cdot 61$ \\
\hline
\end{tabular}

Day 1 was most commonly reported by exposed participants as the date of onset of the principal symptoms identified, apart from skin irritation (day 2) (figure). These continued intermittently, 97\% having resolved by day 7 . There were no differences in dates of onset of reported symptoms or the proportions of subjects reporting specific symptoms between those exposed outside and inside. The differences found within the exposed group for diarrhoea and nausea before and after the incident were contributed by the geographical location furthest from the wreck.

Of those tested there were no significant differences between the exposed and control groups for mean height, weight, or peak expiratory flow distributions, nor for urinary, haematological, renal, or liver function results, nor in the proportions outside the laboratory normal values corrected for age and sex. The same measurements on those who had outside exposure showed no differences between exposed and control participants; the only significant differences between those exposed mainly outside compared with inside were in peak flow and in serum creatinine, $\gamma$-glutamyltransferase, alanine aminotransferase, and haemoglobin concentrations. These differences disappeared after correction for the laboratory normal values for age and sex (and height for peak expiratory flow), apart from haemoglobin concentration, which remained significantly higher in the outside group $\left(\chi^{2}=8.64\right.$, $\mathrm{df}=2, \mathrm{p}<0.02$ ) (table III).

No methylhippurate isomers were detected in the

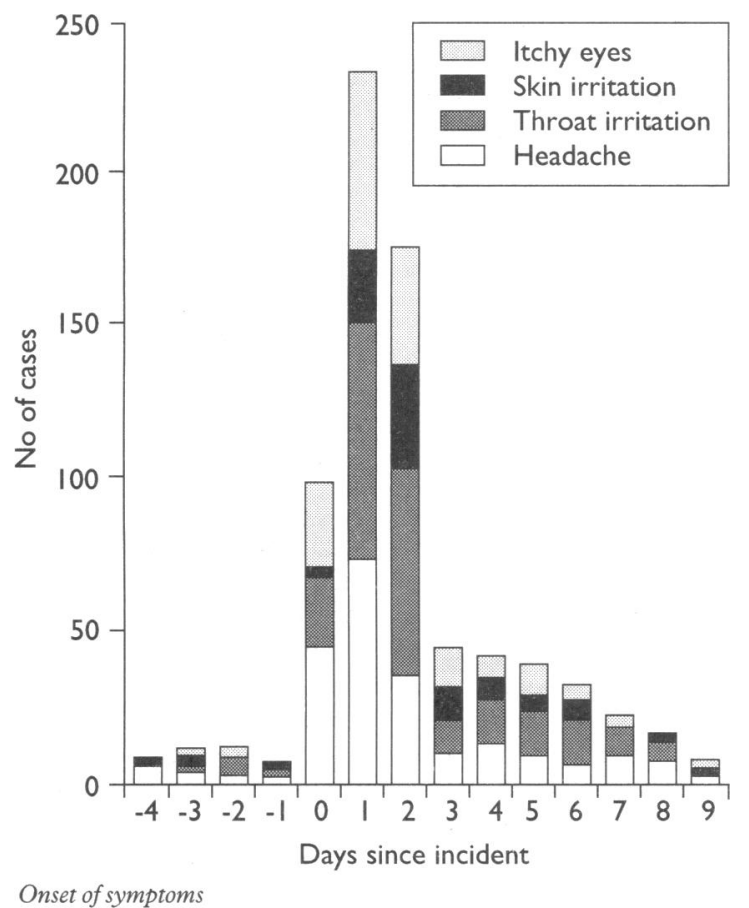

urine samples (limit of detection $0 \cdot 1 \mathrm{~g} / \mathrm{l}$ ) and only four urinary hippurate:creatinine ratios $>1 \mathrm{~g} / \mathrm{g}$ (limit of detection of hippuric acid $0.05 \mathrm{~g} / \mathrm{l}$ ) were reported. In two of these cases the subjects had very low urinary creatinine concentrations; one of these subjects, a child, also had a low serum creatinine concentration. A repeat sample in one of the others three days later produced a normal result. There was a greater proportion of detections of urinary hippuric acid in the exposed group than in the controls $\left(34 \% v 16 \%, \chi^{2}=\right.$ $10.02, \mathrm{df}=1, \mathrm{p}<0.002)$ but no significant differences in the mean hippurate:creatinine ratios $(0.30 v 0.21$ $\mathrm{g} / \mathrm{g}$ ). No significant differences were found in the proportions of detections of hippuric acid by sampling date nor of daily mean hippurate:creatinine ratios (table IV). The examinations for volatile substances in blood showed only butanol and tertiary butanol in all samples and ethanol in three exposed people, the maximum level being $0.95 \mathrm{~g} / \mathrm{l}$.

TABLE IV-Detection of urinary hippuric acid and mean hippurate: creatinine ratios of exposed participants by day of sample

\begin{tabular}{lccc}
\hline Days & $\begin{array}{c}\text { No of } \\
\text { samples }\end{array}$ & $\begin{array}{c}\text { No with hippuric } \\
\text { acid }\end{array}$ & $\begin{array}{c}\text { Mean } \\
\text { hippurate:creatinine ratio } \\
(\mathrm{g} / \mathrm{g})(95 \% \text { confidence } \\
\text { interval) }\end{array}$ \\
\hline 7 & 31 & 11 & $0.38(0 \cdot 16$ to $0 \cdot 60)$ \\
8 & 103 & 30 & $0 \cdot 18(0 \cdot 12$ to $0 \cdot 24)$ \\
9 & 124 & 39 & $0 \cdot 36(0 \cdot 30$ to $0 \cdot 42)$ \\
10 & 102 & 43 & $0 \cdot 26(0 \cdot 20$ to $0 \cdot 32)$ \\
11 & 17 & 5 & $0 \cdot 81(0 \cdot 21$ to $1 \cdot 41)$ \\
12 & 12 & 4 & $0 \cdot 24(0 \cdot 11$ to $0 \cdot 37)$ \\
\hline
\end{tabular}

\section{Discussion}

The Braer incident has to be seen in the context of there having been 17 oil spills of over 20000 tonnes worldwide since the Torrey Canyon in $1967 .{ }^{10}$ Big spills dominate public perceptions, but only about half the oil entering the world's oceans originates from ships, principally from tank flushing; the remainder is from routine releases from machinery, vehicles, etc. The previously reported studies into the health effects of major oil spills by the Amoco Cadiz in 1978 and the Exxon Valdez in 1989 focused on those occupationally exposed. ${ }^{56}$ This project is unique in studying the health of an exposed resident community, acquiring symptom and biological data in the immediate aftermath of the spill and being able to establish a cohort for further study.

Crude oil is a complex mixture of many chemical compounds, mostly hydrocarbons. ${ }^{112}$ In general, North Sea crudes are less dense and contain a higher proportion of volatile compounds than those from the Middle East or South America. Gullfaks is not typical, being more naturally biodegraded, which removes most of the waxy normal paraffins, resulting in a heavier, more naphthenic and aromatic crude 
(Statoil, personal communication). The aromatic petroleum hydrocarbons of toxicological interest are benzene, alkyl benzenes (principally toluene and xylene), and polynuclear aromatic hydrocarbons. ${ }^{13}$ Gullfaks contains traces of metals, notably nickel and vanadium, and less than $1 \%$ by weight of sulphur. The dispersants used consisted mainly of surfactants and solvents. ${ }^{3}$

Knowledge of human responses to acute exposures to petroleum components comes from studies with solvents containing benzene and with petroleum..$^{74}$ Recognised human biochemical and physiological responses associated with acute exposures to natural crudes are mainly transient and short lived unless the concentrations of components are unusually high. Such exposures irritate the skin, cause stinging or redness of the eyes on accidental contact or exposure to the vapours or aerosols, and can produce nausea, dizziness, headache, or drowsiness on prolonged or repeated exposure to low concentrations of their volatile components. An occupational exposure limit of $100 \mathrm{ppm}$ (as time weighted average over eight hours) has been adopted for the vapour. There is no recognised limit for crude oil aerosol, though the Health and Safety Executive has approved an occupational exposure standard of $5 \mathrm{mg} / \mathrm{m}^{3}$ for mineral oil mist. ${ }^{15}$ Inhalation of mineral oils may cause lipoid pneumonia; this is a rare condition and several investigations on the effect of industrial exposure have failed to find harmful pulmonary effects. ${ }^{16}{ }^{17}$

Areas of particular concern included exposure to benzene, toluene, and xylene. High concentrations $\left(>3000 \mathrm{mg} / \mathrm{m}^{3}\right)$ of benzene cause neurotoxic symptoms, and prolonged exposure to toxic levels may cause bone marrow damage with persistent pancytopenia. ${ }^{18}$ Demonstrable health effects have not been found at exposures below $100 \mathrm{mg} / \mathrm{m}^{3}$, and the significance of the chromosome damage reported at $16 \mathrm{mg} / \mathrm{m}^{3}$ is not clear. As there is no determined threshold for the carcinogenic effect on blood forming tissues, the Health and Safety Executive has set a maximum exposure limit of $16 \mathrm{mg} / \mathrm{m}^{3}$ in an eight hour time weighted average. ${ }^{15}$ The primary health effects of toluene and xylene are on the central nervous system. ${ }^{1920}$ Acute exposure at levels above $375 \mathrm{mg} / \mathrm{m}^{3}$ of toluene have caused fatigue, confusion, and incoordination. Headache, nausea and vomiting, dizziness, and vertigo have been reported at an inhalation exposure level of xylene of $3000 \mathrm{mg} / \mathrm{m}^{3}$, and eye, nose, and throat irritation have been described at concentrations of $435 \mathrm{mg} / \mathrm{m}^{3}$. There are no adequate data on the incidence of cancer after human exposure to either chemical. The Health and Safety Executive has set long term occupational exposure limits of $188 \mathrm{mg} / \mathrm{m}^{3}$ for toluene and $435 \mathrm{mg} / \mathrm{m}^{3}$ for xylene and short term exposure limits (10 minute reference period) of $560 \mathrm{mg} / \mathrm{m}^{3}$ and $650 \mathrm{mg} / \mathrm{m}^{3}$ for the compounds. ${ }^{15}$ No conclusive evidence of teratogenic potential or for reproductive effects have been presented for benzene, toluene, or xylene.

The representativeness of the exposed group studied of the total study population, the absence of differences between participants and non-participants, and the successful selection of the controls lends credence to the conclusions that can be drawn from this study. It is also unlikely that there was differential reporting of symptoms by the exposed and control groups based on their assumptions of the hypothesis being tested. The principal health effects found are those to be expected from acute exposure to petroleum hydrocarbonsnamely, headache, throat irritation, and itchy eyes. The peak day of their onset coincided with anecdotal descriptions of the smell of petroleum being most obvious. No detectable increases occurred in association with the short lived peak of exposure as determined by environmental monitoring. The reports of tiredness could be equally attributable to the increased occupational demands being made on many of the exposed participants. This study did not examine specifically the psychological health of the exposed population, that being the subject of a separate exercise (L Cooke, personal communication). However, in light of lessons learned from the Camelford incident, one of the aims of the study was to minimise the opportunity for "real mental and physical suffering" in the people of Shetland. ${ }^{21} 22$ The control group seems to have experienced upper respiratory tract infections in the preceding two weeks while a geographical group within the study area was experiencing gastrointestinal symptoms during the data collection period. Serum samples from people complaining of these gastrointestinal and respiratory symptoms were tested for viruses but no diagnostic titres were obtained, the samples possibly having been taken too soon after the onset of the clinical symptoms.

It could be postulated that exposure to both hydrocarbons and dispersants would have been greater in those with outside activities. This study cannot definitely determine whether aerial spraying of dispersants further contributed to health effects. There were no differences, however, in dates of onset of reported symptoms or the proportions of people reporting specific symptoms between those exposed outside and inside, findings that might have been expected if dispersants had clinically affected exposed people. The lack of sufficiently detailed air monitoring data until day 5 precluded the examination of any relation between symptoms and possible exposure dosage. The postcode information collected lacked sufficient precision for attempting to determine a relation between symptoms and distance from the Braer.

The absence of significant differences in biological markers is not surprising. Major exposures would have been required materially to affect liver and renal function; these were not found by the environmental monitoring performed. Effects on the haemopoietic system would not have been expected to be manifest in samples taken so soon (a maximum of 14 days) after the exposure. The higher haemoglobin concentrations in those exposed outside might be associated with their greater physical activities. Urinary hippurate: creatinine ratios greater than $1 \mathrm{~g} / \mathrm{g}$ suggest that the possibility of exposure to toluene should be investigated. ${ }^{18}$ Toluene is not the only source of urinary hippuric acid, which is a normal constituent of urine and may originate from food containing benzoic acid or benzoates. While this study's toxicological sampling did not start until day 8 , urine samples were also collected from some exposed people from days 3 to 13 ; none of these showed methylhippuric isomers or hippurate:creatinine ratios greater than $0.75 \mathrm{~g} / \mathrm{g}$ (C Rowlands, personal communication). The lack of methylhippurate isomers in any of the urine samples showed the absence of xylene metabolites. Neither series of samples indicated exposures to levels of toluene or xylene that could affect human health or any detectable increase that could indicate a dose-response relation in association with the maximum environmental exposure on day 6 . The presence of butanol and tertiary butanol is an artefact that can occur in the blood tubes used for sample collection. The people with raised concentrations of ethanol, one of whom also had a raised concentration of $\gamma$-glutamine aminotransferase, were men who admitted consuming in excess of 15 units of alcohol per week.

It is reassuring that the principal demonstrable effects on the population were of seemingly minor clinical symptoms and that major abnormalities in biological markers were absent. This does not preclude some people having experienced more severe effects. 


\section{Public health implications}

- Previous studies on exposures to oil spillages had concentrated on workers involved in clean up activities rather than on an exposed population

- Symptoms reported by the exposed population after the Shetland oil spill were compatible with hydrocarbon exposure

- This study showed no laboratory evidence of acute health effects

- Rapid epidemiological responses to environmental incidents are necessary and feasible

Assessment of the longer term sequelae of this incident will require further monitoring of the exposed population. The next phase of the study, planned for five to six months after the grounding of the Braer, will examine the health experiences and psychological status of the exposed and control cohorts since the incident and repeat measurements of their biological markers. It is also proposed that the NHS central register's record of each exposed person be flagged so that important health events (cancer registration and death) affecting this population can be determined.

These findings were presented to the people of the South Mainland of Shetland at a public meeting.

We thank the staff of the laboratories in the Gilbert Bain Hospital, Lerwick; the National Poisons Unit, London; and the Department of Forensic Medicine and Science, Glasgow University. Without the cooperation of the people of Shetland this study could never have occurred. This work was supported by funding from the secretary of state for Scotland. The views expressed are those of the authors.

Members of the Shetland Health Study Group were: $\mathrm{Mr} \mathrm{C}$ Cumming, Gilbert Bain Hospital, Shetland; Dr V S G Murray, National Poisons Unit, London; $\mathrm{Dr} J$ S Oliver, Glasgow University, Glasgow; Dr A Proudfoot, Edinburgh Royal Infirmary, Edinburgh; Mrs $M$ Stove, Mrs M Robertson, Miss K Hudson, Shetland Health Board, Shetland; Dr M D Hunter, Dr C M Rowlands, Mrs S Mann,
Levenwick Medical Practice, Shetland; Dr A Min, Mrs S Thompson, Hillswick Medical Practice, Shetland; Mr M R Hall, Shetland Islands Council, Shetland; Dr G I Forbes, Environmental Health (Scotland) Unit, Glasgow.

1 Christie B. Shetland oil spill prompts health checks on islanders. $B M$ 1993:306:230.

Smith G. Islanders fear health risk from the polluted mist of spilled oil. The Herald 1993;9 January: 1,5.

3 Dalyell T. Toxicity and troubled waters. New Scientist 1993;20 February:50.

4 Bingham E, Trosset RP, Warshansky D. Carcinogenic potential of petroleum hydrocarbons. A critical review of the literature. 7 Environ Pathol Toxicol 1979;3:483-563.

5 Menez JR, Berthou F, Picaut D, Riche C. Impacts of the oil spill Amoco Cadiz on human biology. Penn Ar Bed 1978;94:367-78.

6 Gorman RW, Berardinelli SP, Bender TR. Health hazard evaluation repor HETA 89-200 and 89-273-2111, Exxon/Valdez Alaska oil spill. Cincinnat: Hazard Evaluation and Technical Assistance Branch, NIOSH, US Department of Health and Human Services, 1991.

7 Delzell E, Austin H, Cole P. Epidemiologic studies of the petroleum industry. In: Weaver NK, ed. Occupational medicine: state of the art reviews. Vol 3. Philadelphia: Hanley and Belfus, 1988:455-75.

8 Campbell DM. Shetland oil spill. BMf 1993;306:519.

9 Dean AG, Dean JA, Burton AH, Dicker RC. Epi Info, version 5: a word processing, database, and statistics program for epidemiology on microcomputers. processing, database, and statistics program

10 Pearce F. What turns an oil spill into a disaster? New Scientist 1993;30 January:11-3.

11 Smith HM Qualitative and quantitative aspects of crude oil composition. Bureau of Mines Bulletin 1968;642:136.

12 King RW. Petroleum: its composition, analysis and processing. In: Weave NK, ed. Occupational medicine: state of the art reviews. Vol 3. Philadelphia: Hanley and Belfus, 1988:409-30.

13 MacFarland HN. Toxicology of petroleum hydrocarbons. In: Weaver NK, ed. Occupational medicine: state of the at reviews. Vol 3. Philadelphia: Hanley and Belfus, 1988:445-54.

14 Zedeck MS. Polycyclic aromatic hydrocarbons-a review. I Environ Patho Toxicol 1980;3:537-67.

15 Health and Safety Executive. Occupational exposure limits 1993. London: HMSO, 1993. (EH40/93.)

16 Goldstein DH, Bendit JN. An epidemiologic study of an oil mist exposure. Arch Environ Health 1970;21:600-3.

17 Jarvholm B, Bake B, Lavenius B, Thiringer G, Vokmann R. Respiratory symptoms and lung function in oil mist-exposed workers. 7 Occup Med 1982;24:473-9.

18 Fielder RJ, Sorrie GS, Bishop CM, Gompertz D, Fletcher AP, Van den Heuvel MJ. Toxicity to man. In: Health and Safety Executive. Benzene. Toxicity review 4. London: HMSO, 1982:11-24.

19 Bell GM, Battershill JM, Shillaker RO. Toxicity to humans. In: Health an Safety Executive. Toluene. Toxicity review 20. London: HMSO, 1989:34-48.

20 Bell GM, Shillaker RO, Padgham MDJ, Standring P. Toxicity to humans. In Health and Safety Executive. Xylenes. Toxicity review 26. London: HMSO, 1992:25-8.

21 Lowermoor Incident Health Advisory Group. Water pollution in Lowermoor North Cornwall. Truro: Cornwall and Isles of Scilly Health Authority, 1989.

22 Lowermoor Incident Health Advisory Group. Water pollution in Lowermoor, North Cornwall. Second report. London: HMSO, 1990.

(Accepted 24 August 1993)

\section{Acute myocardial infarction in patients with normal coronary arteries}

\section{Cardiac Department, London Chest Hospital, London E2 9]X \\ Stephen J D Brecker, research fellow \\ Robert N Stevenson, research fellow \\ Robin Roberts, research \\ fellow}

Subramaniam

Uthayakumar, senior chief medical laboratory scientific officer

Adam D Timmis, consultant cardiologist

Raphael Balcon, consultant cardiologist

Correspondence to: Dr S J D Brecker, Cardiac Department, Royal Brompton National Heart and Lung Hospital, London SW3 6NP.

BMf 1993;307:1255-6

\section{Stephen J D Brecker, Robert N Stevenson, Robin Roberts, Subramaniam Uthayakumar, Adam D Timmis, Raphael Balcon}

Acute myocardial infarction in patients with normal coronary arteries has been recognised for several years ${ }^{1-3}$; its aetiology is unknown, although spasm, emboli, and platelet dysfunction have been postulated as causes. The incidence of prothrombotic syndromes in such patients is unknown, and clinicians remain uncertain about how aggressively to pursue investigation. We studied haematological variables associated with a prothrombotic tendency in patients with normal coronary arteries after a myocardial infarction and compared findings with those in patients whose myocardial infarction had been associated with obstructive coronary disease and in normal subjects.

\section{Patients, methods, and results}

Over 18 months 2478 patients had a cardiac catheter for investigation of coronary artery disease in this department; 342 had been referred after a suspected myocardial infarction. Of these, 12 patients had normal epicardial coronary vessels on angiography, a classic history, definite electrocardiographic changes, and a diagnostic increase in cardiac enzyme activity or regional hypokinesis on left ventriculography performed a median of 11 days (range 5-120) after infarction. We compared findings with those in patients randomly drawn from the study population who had a stenosed or occluded vessel associated with infarction. A control group consisted of healthy hospital employees who were matched for age and sex. Blood samples were taken from all patients a median of seven months (3-21) after infarction.

The patients with normal coronary arteries were younger than those with coronary artery disease, but the sex distribution, site of infarction, and risk factor profiles were similar in the two groups. Myocardial infarction was unheralded in all those with normal coronary arteries but preceded by angina or infarction in seven of the 11 with coronary artery disease. Two of the three women with normal coronary arteries were taking the contraceptive pill. Mean packed cell volume platelet count, fibrinogen concentration, viscosity, and clotting screens did not differ significantly between any of the groups, and no patient had antithrombin III, protein C, or protein S deficiency or lupus anticoagulant. Mean plasminogen concentration, plasminogen activator inhibitor concentration, and 